\title{
¿AHÍ VIENEN LOS DIABLOS! Narrativas e espaços de performance em um ritual de rebelião patrimonializado
}

\author{
Amarildo Ferreira Júnior \\ Instituto Federal de Educação, Ciência e Tecnologia de \\ Roraima - IFRR \\ Silvio Lima Figueiredo \\ Professor e pesquisador do NAEA/UFPA \\ Rosa Elizabeth Acevedo Marín \\ Professora e pesquisadora do NAEA/UFPA
}

\begin{abstract}
Resumo: Reconhecidos como Patrimônio Cultural Imaterial da Humanidade, os Diablos de Yare protagonizam uma festa em que pessoas usando máscaras de diabos integram o ritual público da festa, missa e procissão de Corpus Christi, ora se constituindo um corpo mais ou menos independente, ora se ligando à celebração litúrgica. Este artigo discute a produção de sentidos a respeito deste ritual de rebelião e da espacialização de significados políticos e sociais de suas performances, por meio de dados coletados em trabalho de campo (2015) e em pesquisa documental e bibliográfica. Considerando-a como um campo de relações em que emergem cenas de performances e discursos, com inversões simbólicas e afirmação de identidades coletivas, nas quais se movimentam aspectos étnico-sociais e econômicos, constata-se que, nesta compósita manifestação cultural-religiosa, são mobilizados sentidos e significados que permitem ressignificar os agenciamentos e enquadramentos que recebem ao mesmo tempo em que produzem lugares de experimentação, representação e resistência.
\end{abstract}

Palavras-chave: festa; Diablos Danzantes; sentidos; performance. 


\title{
¿AHÍ VIENEN LOS DIABLOS! Narratives and performance spaces inside a ritual of rebellion recognized as cultural heritage
}

\begin{abstract}
Recognized as Intangible Cultural Heritage of Humanity, the Diablos de Yare play a festivity which people who wear masks of devils integrate a public ritual of party, mass and procession of Corpus Christi, one moment more or less as an independent body, the next connecting to liturgical celebration. This article discusses the production of meanings about the ritual of rebellion and specialization of performance's political and social meanings, by means of collected datas inside fieldwork (2015) and documental and bibliographic research. Considering as a field of relations where emerge scenes of performances and speeches with symbolic inversions and affirmative collective identities, in which ethnical, social and economic aspects move around, it is noted that this complex cultural-religious manifestation mobilize purport and meanings that provides resignify agency and framework which receive and produce at the same time places of experimentation, representation and resistance.
\end{abstract}

Key-words: party; Diablos Danzantes; meanings; performance.

\section{¿AHÍ VIENEN LOS DIABLOS! Narraciones y espacios de performance en un ritual de rebelión hecho patrimonio cultural}

Resumen: Reconocidos como Patrimonio Cultural Inmaterial de la Humanidad, los Diablos de Yare protagonizan una fiesta en que personas que lucen máscaras de diablos hacen parte del ritual público de la fiesta, misa y procesión de Corpus Christi, constituyéndose en algunos momentos un cuerpo relativamente independiente, y en otros ligándose a la celebración litúrgica. En este artículo discutimos la producción de sentidos acerca de dicho ritual de rebelión y la espacialización de significados políticos y sociales de sus performances, con el uso de datos recolectados en trabajo de campo (2015) e investigaciones documental y bibliográfica. Mirándola como un campo de relaciones en donde surgen escenas de performances y discursos, con cambios simbólicos y afirmación de identidades colectivas, en las cuales se mueven aspectos étnico-sociales y económicos, percibiese que en esta compósita manifestación cultural-religiosa, se movilizan sentidos y significados que hacen posible la re-significación de las agencias y encuadres que sufre en el mismo tiempo que se producen lugares de experimentación, representación y resistencia.

Palabras clave: fiesta; Diablos Danzantes; sentidos; performance. 


\section{INTRODUÇÃO}

Anualmente, na quinta-feira em que se celebra Corpus Christi, centenas de pessoas saem às ruas de San Francisco de Yare, capital do município Simón Bolívar (estado Miranda, Venezuela), vestindo trajes vermelhos e coloridas máscaras de diabos, em uma série de performances rituais marcadas pelo som de instrumentos de percussão. Conhecidos como Diablos Danzantes de Yare, estas pessoas integram o conjunto de festividades denominadas Diablos Danzantes de Corpus Christi de Venezuela, existentes em localidades do centro e da costa venezuelana, e reconhecidas desde o ano de 2012 como Patrimônio Cultural Imaterial da Humanidade pela United Nations Educational Scientific and Cultural Organization (Unesco)1.

Este artigo 2 traz reflexões sobre essa festa originadas a partir de dois momentos. O primeiro constitui-se de um conjunto de debates e discussões que articularam perspectivas teórico-interpretativas do conflito social - suas dimensões sociais, jurídicas e políticas, e suas relações com o poder -, e da religião - em especial sobre a mística e suas diferentes manifestações. Nesses debates, foram originadas as perspectivas analíticas que permitirão enfatizar o entendimento dos sentidos simbólicos e os significados políticos e sociais desse ritual de rebelião, que aqui serão discutidos.

O segundo momento foi um trabalho de campo, no formato de survey exploratório, realizado entre os dias 29 de maio e o9 de junho de 2015. Naquela ocasião, o objetivo era realizar uma primeira aproximação empírica com a festa e, a partir de então, subsidiar definições metodológicas e de categorias teóricas para a pesquisa. Deste momento se originam os dados aqui analisados, registrados em um diário de campo e em fotografias, e complementados com pesquisa documental e bibliográfica.

\section{A FESTA DO CORPO DE DEUS E OS DIABOS DANÇANTES}

O Corpus Christi é uma festa cristã instituída no calendário eclesiástico da Igreja Católica no ano de 1264 pelo Papa Urbano IV e reafirmada no ano de 1311 pelo Papa Clemente V. Também denominada como a Festa do Corpo de Deus3, é destinada a focalizar a centralidade do mistério eucarístico, e por isso possui relação direta com a Semana Santa e a Páscoa: nestas, a ocasião festiva relembra a instituição da Eucaristia e reflete sobre a Paixão, a Morte e a Ressurreição de

\footnotetext{
${ }^{1}$ Foram onze as confrarias contempladas pelo registro, cada qual mantendo celebrações com algumas características que as distinguem e sendo referenciadas por meio do nome da localidade em que ocorrem: Naiguatá, no estado Vargas; Patanemo e San Millán, no estado Carabobo; Tinaquillo, no estado Cojedes; Cuyagua, Cata, Turiamo, Ocumare de la Costa e Chuao, no estado Aragua; San Rafael de Orituco, em Guárico; e San Francisco de Yare, no estado Miranda.

2 Uma versão preliminar deste texto foi apresentada na $30^{a}$ Reunião Brasileira de Antropologia, realizada entre os dias 03 e 06 de agosto de 2016, em João Pessoa/PB.

3 Segundo Santos (2005, p. 16), a festa também recebeu tal denominação porque "os diferentes corpos sociais que 'iam em procissão’ adorar o Santíssimo Sacramento [...] supunham formar o Corpo de Deus [...]”.
} 
Jesus Cristo, enquanto, no Corpus Christi, a ocasião festiva é destinada a celebrar a vida e reafirmar o mistério eucarístico (SANTOS, 2005).

Considerada uma das festas mais populares do calendário religioso das cidades latino-americanas, nas quais chegou durante os processos de conquista e colonização, o Corpus Christi expressa em diversas dessas localidades uma ampla variedade de manifestações da imaginação e criatividade popular, que se realizam desde sua véspera até o dia de sua oitava4. Dentre essas manifestações, destacam-se estas festas onde alguns diabos dançam perante Deus, e que consistem numa manifestação cultural-religiosa que tem seus antecedentes, afirma Ramos Guédez (2009), na Idade Média5.

Constituem uma atividade humana de caráter coletivo, vinculada a diversos processos de trocas simbólicas, sobretudo de caráter religioso e étnicocultural, pois não apenas coincide com o dia de Corpus Christi, como também incorpora aportes tanto das sociedades indígenas estabelecidas no local antes da conquista espanhola, como dos africanos trazidos escravizados para o país desde as primeiras décadas do século XVI (CADENAS UZCÁTEGUI, 2010; RAMOS GUÉDEZ, 2009).

Através dessas trocas simbólicas, incorporaram-se à festa cristã elementos rituais, musicais e de dança de caráter africano. Segundo Ramos Guédez (2009), tal processo ocorrera por meio da permissão dada em determinadas datas do calendário hagiológico católico pelas autoridades civis e eclesiásticas para que tanto as populações indígenas como os africanos escravizados e seus descendentes pudessem ter um dia livre para celebrar alguns santos e santas católicos, dentre os quais se preferiam aqueles que pudessem ser associados às divindades de suas religiões originárias, o que lhes possibilitou a continuidade da expressão de suas crenças e engendrou uma rica variedade de novos cultos e novas expressões culturais no pretenso Novo Mundo.

Todas essas festividades religiosas se organizavam por meio de confrarias, que são irmandades entre leigos - apesar do caráter religioso -, autorizadas, mas não pertencentes à estrutura da Igreja Católica, e unidas em torno da promoção do culto a um santo ou uma santa, com implicações também de qualidades socioeconômicas e culturais. Geralmente administradas por um Mayordomo6 responsável por gerir os gastos e cuidar dos preparativos para a realização da festa em homenagem à santa ou ao santo patrono da irmandade, tais confrarias se organizam fundamentalmente em função das condições sociais e étnicas de seus membros (RAMOS GUÉDEZ, 2009).

\footnotetext{
${ }^{4}$ Tradicionalmente, a oitava é a celebração litúrgica realizada no oitavo dia após o início de uma festa ou celebração religiosa, de modo que se realiza no mesmo dia da semana em que começou. No caso do Corpus Christi, tem se realizado a celebração litúrgica de sua festa somente no domingo subsequente à quinta-feira de Corpus, uma vez que este é o dia da semana consagrado ao Senhor pela Igreja Católica. Entretanto, as localidades que possuem festas e celebrações tradicionalmente realizadas na quinta-feira de Corpus, como é o caso de San Francisco de Yare, permanecem realizando-as neste dia, sendo celebrada a oitava no domingo subsequente e não oito dias após o seu início.

5 Com a instauração, durante a Idade Média, do Corpus Christi como uma festa pública, autos teatrais começaram a representar para o povo a presença da divindade no Santíssimo Sacramento. Segundo nos revela Santos (2005), nesses autos eram inseridas diversas personagens, dentre as quais, figuras de diabos, para representação da luta entre o Bem e o Mal. Assim, segundo a interpretação dada pela historiografia, os diabos que dançam nas festas de Corpus Christi na Venezuela teriam suas origens nesses autos sacramentais realizados na Península Ibérica, que desde a Idade Média vinham recebendo influências dos mouros.

6 Mordomo, em português. Trata-se de um posto no interior de algumas dessas confrarias, espécie de grão-mestre nomeado em conselho por um período geralmente de um ano.
} 
Originários de processos homólogos ao descrito de forma geral acima, os Diablos Danzantes de Corpus Christi podem ser incluídos num conjunto de manifestações existentes em diversos países da América Latina, definidas como diabladas, mas que em cada caso são realizadas de formas, com sentidos e em datas tão distintas quanto são variáveis suas frequências.

Debruçamos-nos neste artigo sobre alguns aspectos específicos da festa realizada em San Francisco de Yare - localidade a qual, a partir deste momento, nos referiremos somente como Yare7 -, cuja organização é feita pela Cofradía del Santísimo Sacramento de los Diablos Danzantes de Yare, doravante referida apenas como Diablos de Yare.

\section{Diablos de Yare: narrativas de origem}

Festas, eventos, movimentos, em suma, as diferentes situações e tensões sociais sobre a qual exercitamos um movimento de compreensão, parecem exigir-nos a identificação de uma origem, provavelmente pela necessidade de forjar e operacionalizar noções de tempo que tanto se associam à construção do tradicional e da tradicionalidade, como transpassam e mesmo orientam as performances dos sujeitos que as realizam.

Não desconhecemos a complexidade imbricada nestas performances, cujos aspectos rituais e festivos formam um campo de análise marcado, ao menos desde o ano de 1912 - quando Émile Durkheim (1858-1917) publica As formas elementares da vida religiosa -, pelo frequente retorno, revisão, atualização e ampliação de seus elementos constituintes. E, quando o campo patrimonial se aproxima destes bens envoltos nas discussões sobre performance, como são as festas e rituais, surge um díptico em que ambas as partes se constituem elementos constantemente revistos, atualizados e ampliados da outra, permitindo, desse modo, novas e criativas formas de abordagem e, principalmente, soluções de problemáticas colocadas por um ou por outro campo.

Em torno das narrativas de origem de bens culturais e da constituição de noções de tempo que aí se elaboram e operam, as performances podem ser observadas desde o ponto de vista das tomadas de posição dos agentes culturais que passam a representar papeis também no campo patrimonial. Porém, no lugar do procedimento usual de recorrer primeira e prioritariamente aos discursos legitimadores do mundo savant, um aporte mais significativo é partir de outras narrativas, elas mesmas vistas como performances e como matriz de alimentação de outros tipos de performances. Vejamos, sob esta perspectiva, o relato a seguir.

\footnotetext{
${ }^{7}$ San Francisco de Yare é, junto com San Antonio de Yare, uma paróquia do município Simón Bolívar, um dos 21 municípios que conformam o estado Miranda, localizado no centro-norte do território venezuelano, a uma distância de cerca de $70 \mathrm{~km}$ ao sul da capital federal Caracas, e com uma população estimada em 34.686 habitantes, de acordo com o censo de 2011 (INE, 2013).
} 
Era manhã de quarta-feira, três de junho, véspera de Corpus Christi, e Yare estava em intensa movimentação. Cartazes, banners e murais com imagens do Santíssimo Sacramento e de membros dos Diablos de Yare se espalhavam pelo povoado. Pouco a pouco íamos identificando espaços que se destacavam e que, posteriormente, confirmaríamos serem lugares de destaque onde os Diablos de Yare entravam em cena: a Plaza Bolívar de Yare; a Igreja Paroquial San Francisco de Paula, localizada na praça citada; a Casa de los Diablos, sede da confraria; o Museu Casa de Bolívar; a Casa Paroquial; a taverna e o bar. Em frente à Casa Paroquial, Carlos Ernesto Ponte Bello, idoso que vive no município, estava conversando com algumas pessoas interessadas naquela festa.

Narrava alguns fatos e anedotas acerca do município, como a hipótese de que o verdadeiro local de nascimento de Simón Bolívar (1783-1830) não teria sido Caracas, capital do país, como apresentam os registros históricos, mas aquele pequeno povoado localizado nos Valles del Tuy8. Sendo assim, dizia ele, nossas duas revoluções se iniciaram em Yare - a primeira, o processo emancipador do qual Bolívar participou e que ocorrera entre os anos 1810 e 1821, levando à independência do país; a segunda, autodenominada bolivariana, e ainda em cursog.

Quando falava aos curiosos ouvintes sobre o surgimento dos Diablos de Yare, Ponte Bello o relacionava ao agradecimento a Deus por um milagre ocorrido há muito tempo. Segundo nos contou, durante a época da colonização da Venezuela, em que as terras que atualmente conformam Yare eram um conjunto de fazendas cuja base laboral era a mão de obra escravizada, ocorreu uma grande seca, que afetou todas as plantações, ocasionando prejuízos financeiros, escassez de alimentos e enfermidades.

Sem nenhum indício de que a seca fosse cessar, o vigário do povoado, percebendo que as missas estavam cada vez mais desertas, decidiu fazer uma convocatória para que todos os cidadãos do povoado voltassem a frequentar a missa, pois via a estiagem como atuação de forças demoníacas na localidade.

A população não teria atendido à primeira convocatória, levando o vigário a realizar uma nova convocação, dessa vez com mais veemência, dizendo que, se necessário fosse, até o Diabo deveria participar da missa. No dia marcado para a

\footnotetext{
${ }^{8}$ Segundo o relato do senhor Ponte Bello, para quem o nascimento, em Yare, do Libertador é mais que uma hipótese, a suposta existência de registros de que, em finais de julho de 1783, a família Bolívar encontrava-se em suas propriedades no povoado, comprova o que nos narrou. Desse modo, considerando que o deslocamento à Caracas era feito somente a cavalo, Ponte Bello diz-nos que não seria possível à María de la Concepción Palacios de Aguirre y Ariztía-Sojo y Blanco, mãe de Simón Bolívar, transportar-se até a capital tendo, ainda, que suportar as dores do trabalho de parto. Para ele, o registro de que Bolívar nascera em Caracas fora um artifício historiográfico daqueles que acreditavam que se estaria reduzindo a importância de seus atos e da distinção que sua família possuía em meios aristocráticos, caso seu nascimento fora registrado num pequeno povoado como Yare.

9 Segundo afirmou nosso interlocutor, a Revolução Bolivariana também surgiu em Yare porque foi na prisão localizada naquele povoado que, após a efeméride venezuelana conhecida como 4F, Día de la Dignidad Nacional - tentativa de deposição do presidente Carlos Andrés Pérez, por meio de uma rebelião cívico-militar cujos fatos mais frequentemente recordados se deram em 04 de fevereiro de 1992 -, Hugo Rafael Chávez Frías ficara encarcerado por dois anos, tendo gestado, segundo o imaginário bolivariano, os ideais que orientariam o processo revolucionário que demarca o início da chamada V República. Chávez realmente elaborara, durante seu período de cárcere em Yare, alguns esboços do pensamento que colocaria em prática a partir de sua chegada ao poder, no ano de 1999. Dentre esses esboços, figura o manifesto ¿Cómo salir del laberinto?, documento que, para Bermúdez e Martínez (2000), faz parte da construção das chaves discursivas que permitiram construir e orientar a ação coletiva que levou do fracasso do $4 \mathrm{~F}$ à conquista democrática da Presidência da República sete anos depois. Entretanto, deve-se ter cuidado ao colocar sentidos teleológicos a fatos interpretados a posteriori e à luz dos sentidos que podem emprestar para explicar e/ou defender pontos de vistas. Nesse sentido, Bruce (2016) reconstitui a formação da cultura política que sustenta a ascensão e o apoio ao projeto chavista de democracia a fatos anteriores aos sucessos de 1992.
} 
realização da segunda missa, os negros escravizados, em sua maioria, da etnia Mandinga10, afirmou o narrador, decidiram, apesar de proibidos de adentrar nos templos católicos, atender ao chamado do pároco, pois também sofriam graves consequências por conta da estiagem.

Assim, quando tais escravizados, que tinham como uma de suas artes de resistência (SCOTT, 2000) a confecção de máscaras com expressões diabólicas que usavam para assustar seus senhores e, com isso, facilitar a fuga, começaram a chegar à frente da Igreja, o padre teria gritado iAhí vienen los diablos!, lançando água benta em sua direção, para afastá-los. Imediatamente, contounos o narrador, e sem que houvesse sequer uma nuvem no céu, começou a chover, e todos dançaram sob as águas que caíam, os negros de um lado, tocando seus instrumentos de percussão, e os brancos de outro. Por isso, arremata, toda vez que é Corpus Christi, chove em Yare.

\section{A dança dos diabos: breve descrição}

Em Yare, assim como nas outras localidades nas quais os Diablos Danzantes estavam presentes já no período colonial, essa festividade obteve múltiplas expressões. Ao mesmo tempo, suscitaram um conjunto de proibições por parte de alguns bispos e outras autoridades eclesiásticas, sob o argumento de que as máscaras e as indumentárias usadas, além do próprio baile, “[...] turbavam, e inquietavam a devoção [...]”, eram pecaminosas e “[...] consideradas demasiado irreverentes para a ocasião [...]" (RAMOS GUÉDEZ, 2009, p. 169, tradução nossa). Tais proibições eclesiásticas afetaram, sobretudo, as cerimônias religiosas que se realizavam nas cidades, o que fez com que os diablos continuassem efetuando seus rituais e promessas nas zonas rurais.

Devido ao fato das primeiras celebrações de Corpus Christi na Venezuela serem de responsabilidade de autoridades políticas e religiosas, o surgimento dos Diablos Danzantes como um tipo de celebração do catolicismo popular produziu uma sobreposição de sentidos, que fez com que diversos elementos fossem sendo utilizados na composição dessa festa (GARCÍA GAVÍDIA, 2002), inclusive na formação das confrarias que as realizam, cada qual com características visuais, técnicas corporais11 e organização próprias. Tais confrarias possuem, portanto, uma estrutura que lhes é própria, que varia conforme a referência que se toma dentre as onze confrarias citadas anteriormente.

\footnotetext{
${ }^{10}$ Na Venezuela, o termo Mandinga é uma das formas de se nomear o Diabo. Gallegos (1985, p. 21) assim escreveu em Pobre Negro: - Cuando llegué a lo alto del cerrajón, tuavía se sentia la olor de azufre que deja Mandinga donde se aparece (negrito nosso).

11 Para a definição da noção de técnicas e movimentos corporais, sugerimos dirigir-se a sua formulação em Mauss (1979).
} 


\section{Identidade estética, hierarquias e técnicas corporais na festa dos Diablos de Yare}

$\mathrm{O}$ aspecto mais evidente do fato de vestir-se de diabo durante o Corpus Christi em Yare é representando como sendo uma ação de devoção popular para humilhar o Mal ante as forças celestiais do Bem (MARTíN, 2015), em que aquele é representado nos trajes vermelhos e nas máscaras ferozes e coloridas, enquanto este é simbolizado por adornos protetores, amuletos sagrados trazidos junto às roupas, como rosários e escapulários envoltos no pescoço, medalhas de santos, guizos e cincerros dependurados nos cintos das calças, e cruzes de diversos materiais, em especial de pedaços de folhas bentas de palmeira costuradas em determinados pontos dos trajes12.

Há uma identidade estética própria entre os Diablos de Yare, que também se relaciona com a hierarquia da dança (Quadro 1). O vermelho é predominante nas roupas que vestem, feitas de algodão ou popelina (Figura 1), e, normalmente nessa mesma cor, os diablos trajam alpargatas, longas meias e capas de pano, amarradas nas cabeças dos promesseiros, com máscaras, de diversos tamanhos, presas em sua extremidade. Tais máscaras são inspiradas em animais - reais ou míticos -, possuidores de chifres, como dragões, carneiros e bois, afinal, como conta o artesão e promesseiro Diego Ramírez, o diabo se apresenta de diversas formas: pode ser um carneiro, mas também pode ser um cão.

Quadro 1 Hierarquia da dança

\begin{tabular}{|c|c|}
\hline Posto & Descrição \\
\hline $\begin{array}{l}\text { Primero Capataz } \\
\text { ou Diablo Mayor }\end{array}$ & $\begin{array}{l}\text { Autoridade máxima vitalícia da dança. É o mais velho em idade e o mais } \\
\text { antigo membro da confraria, e sua máscara é a única que possui quatro } \\
\text { chifres. Na mão esquerda, leva um mandador (uma garrocha feita de } \\
\text { madeira ou um chicote), símbolo de poder, que utiliza para amedrontar } \\
\text { qualquer um que interfira no cortejo ou na dança dos diabos; na mão } \\
\text { direita, possui uma maraca em forma de diabo que serve para marcar o } \\
\text { ritmo da dança. É ele quem marca o ritmo e define o percurso a ser feito } \\
\text { pelas ruas do povoado, com todos os demais, promesseiros e } \\
\text { espectadores, não importando suas posições sociais em momentos } \\
\text { alheios ao ritual, devendo lhe prestar respeito. }\end{array}$ \\
\hline $\begin{array}{c}\text { Segundo e } \\
\text { Tercero Capataz }\end{array}$ & $\begin{array}{l}\text { São os ajudantes do Primero Capataz, a quem auxiliam na direção, } \\
\text { organização e desenvolvimento da dança. Suas máscaras possuem três } \\
\text { chifres e em suas mãos levam um mandador e uma maraca. Junto com o } \\
\text { Primero Capataz, iniciam e terminam a dança nos diversos locais } \\
\text { visitados durante a realização da festa. }\end{array}$ \\
\hline Arreadores & $\begin{array}{l}\text { Responsáveis por manter a ordem da dança e zelar pelo cumprimento } \\
\text { dos passos, pelas imagens colocadas nos altares e pelos deslocamentos } \\
\text { dos cortejos. Suas máscaras também possuem três chifres, sendo o } \\
\text { terceiro menor do que o correspondente do segundo e do tercero } \\
\text { capataz. Levam nas mãos um mandador, com o qual simulam fustigar os } \\
\text { dançantes que descumprem as normas da dança. }\end{array}$ \\
\hline $\begin{array}{l}\text { Diablos } \\
\text { ou Prom }\end{array}$ & $\begin{array}{l}\text { São pessoas que cumprem todos os anos promessas feitas ao Santíssimo } \\
\text { Sacramento do Altar, constituindo-se no maior contingente de } \\
\text { participantes da dança (em 2015, a confraria informou que cerca de }\end{array}$ \\
\hline
\end{tabular}

\footnotetext{
12 Os pontos em que são costuradas essas cruzes são na altura do peito (lado esquerdo) e nas costas das camisas, e em cima das capas de pano que prendem as máscaras, no caso dos homens, e sobre o lenço que cobre a cabeça das mulheres. Essas cruzes representam uma sorte de selo, que, junto com outros símbolos e ritos, evita que os promesseiros sejam possuídos pelas forças demoníacas à espreita. As folhas com que são confeccionadas são as mesmas que a Igreja distribui no Domingo de Ramos, o que sinaliza para ampliação do ciclo ritual da festa.
} 


\begin{tabular}{|c|c|}
\hline & $\begin{array}{l}\text { 2.500 Promeseros participaram da festa). Suas máscaras possuem dois } \\
\text { chifres. }\end{array}$ \\
\hline Cajeros & $\begin{array}{l}\text { São os responsáveis por conduzir o ritmo da dança através do toque de } \\
\text { um tambor alargado, com caixa de madeira, denominado de caja. } \\
\text { Durante a festa, somente uma caja é tocada, na qual os Cajeros se } \\
\text { revezam, com a primazia para tocá-la nos pontos altos do ritual sendo do } \\
\text { Primero Cajero, o mais velho em idade e mais antigo na confraria entre } \\
\text { eles. Os Cajeros não utilizam máscara, levando um lenço vermelho } \\
\text { amarrado em volta da cabeça. }\end{array}$ \\
\hline Portaestandarte & $\begin{array}{l}\text { É um promesseiro que percorre as ruas do povoado levando o pavilhão } \\
\text { vermelho da confraria. Assim como os Cajeros, não usa máscara, e } \\
\text { também leva um lenço vermelho na cabeça. É ele quem vai à frente dos } \\
\text { cortejos. }\end{array}$ \\
\hline La Capataz & $\begin{array}{l}\text { Máxima autoridade feminina da festa, a Primera, a Segunda e a Tercera } \\
\text { Capataz são as únicas mulheres que se vestem de vermelho, com um } \\
\text { lenço da mesma cor na cabeça, mas sem máscara. São encarregadas de } \\
\text { auxiliar os Capatazes, colocando-se ao lado deles durante o momento de } \\
\text { direção da dança, e seriam as únicas mulheres autorizadas a dançar. No } \\
\text { entanto, entre os Diablos de Yare as demais mulheres podem dançar, } \\
\text { desde que diante de um altar e tendo pedido autorização ao Primero } \\
\text { Capataz. Para isso, emprestam máscaras dos promeseros que possuam o } \\
\text { mesmo grau hierárquico que elas. }\end{array}$ \\
\hline Arreadoras & $\begin{array}{l}\text { Possuem funções semelhantes aos arreadores, sendo auxiliares das } \\
\text { Capatazes. Vestem blusas brancas - ornadas com medalhas do } \\
\text { Santíssimo Sacramento e de outros santos, e com a indicação do posto de } \\
\text { arreadora bordada no lado esquerdo do peito -, e saias vermelhas, com a } \\
\text { cabeça coberta por um lenço nessa mesma cor. Não utilizam máscara e } \\
\text { levam maraca em uma das mãos e mandador na outra. }\end{array}$ \\
\hline Homes & $\begin{array}{l}\text { São as demais mulheres que integram a confraria. Vestem-se de igual } \\
\text { forma que as arreadoras. }\end{array}$ \\
\hline
\end{tabular}

Fonte: Martín (2015), Ramos Guédez (2009), e trabalho de campo (2015).

Figura 1 Diablos de Yare aguardando o momento para se posicionar em frente à igreja

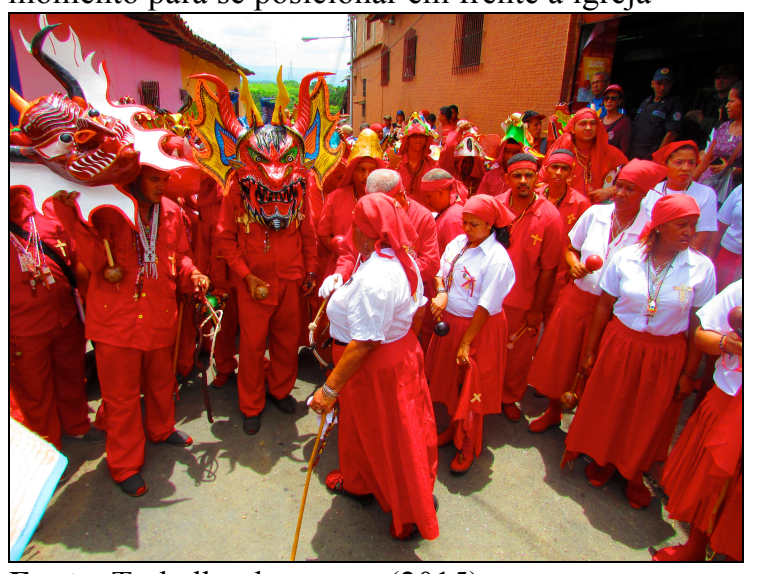

Fonte: Trabalho de campo (2015).
Figura 2 Diablos ajoelhados perante altar armado no interior de uma residência

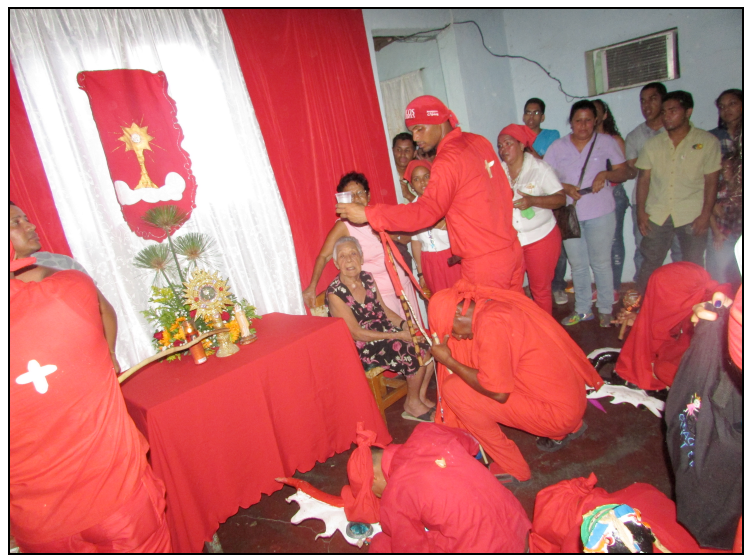

Fonte: Trabalho de campo (2015).

A hierarquia que rege a dança é definida pelo número de chifres da máscara, que vai de quatro chifres (Primero Capataz) a dois (Promeseros), sendo que o Cajero, o Portaestandarte, a Capataz, as Arreadoras e as Promeseras não utilizam máscaras. Coexiste com esta hierarquia outra forma de organização de seus membros, que por ora chamaremos de hierarquia formal, 
baseada em aspectos administrativos e burocráticos da confraria enquanto associação civil regida formalmente por um estatuto13.

Além dos membros da confraria, também participam da festividade uma grande quantidade de pessoas, sejam homens, mulheres, crianças ou jovens, de diferentes grupos étnico-religiosos, que têm que pagar alguma promessa ao Santíssimo Sacramento, e, para isso, montam altares14 diante dos quais os diablos dançam (Figura 2, acima), ou que participam pelo interesse em conhecer esse tipo de expressão cultural-religiosa.

Além do simbolismo da luta entre o Bem e o Mal estar presente nos trajes usados pelos diablos, talvez a forma mais explícita de tal representação é a própria dança, que em determinados momentos está vinculada aos ritos eclesiásticos, e em outros, se desvincula do controle efetivo da Igreja sobre sua execução. Esta dança - técnica corporal -, acontece em diversos momentos e locais, cada qual com características próprias, e possui alguns passos estabelecidos.

A dança sempre é iniciada e finalizada pelos Capatazes, sendo estes os únicos que dançam em todos os espaços de realização da festa, num esforço extraordinário15. Após eles, os demais dançam em levas de grupos, normalmente utilizando como critério de ordem a idade, a posição hierárquica e o tempo de confraria que cada promesseiro possui. Os diablos dançam com os rostos cobertos por uma capa vermelha, que é amarrada na nuca, e na qual a máscara fica pendurada, voltada para baixo ("máscara abajo"), ao som da caja, com o som dos chocalhos e maracas que sacodem em suas mãos, e dos guizos e cincerros dependurados em seus trajes, contribuindo para compor esta cerimônia musical.

Em seguida, muda-se o toque da caja, que passa a ser uma marcação acompanhada pelos chocalhos e maracas, e os diablos se ajoelham por alguns instantes perante o altar (ou a igreja ou o Santíssimo Sacramento, dependendo do momento desse processo ritual em que se encontram), gesto de reverência, de reconhecimento e de rendição dos promesseiros e dos próprios demônios, entidades sobrenaturais, ao Santíssimo. Durante esses instantes, a marcação do ritmo segue, e, progressivamente, o Cajero retoma o toque anterior, quando os diablos ajoelhados se levantam e para se retirarem da frente do altar, caminhando para trás, sem virarem-lhe as costas e com as máscaras ainda voltadas para baixo, como se estivessem sendo repelidos pela santidade ali

\footnotetext{
13 Devido aos objetivos deste artigo, não abordaremos a hierarquia formal e a maneira como se entrelaça com a forma de organização da dança, que por ora chamaremos de hierarquia ritual, embora reconheçamos o caráter profícuo dessa questão para discussões futuras.

14 Estes altares são armados em diversos locais, desde residências de promesseiros (em alguns casos, na frente da residência, em outros, no pátio ou quintal, e, em alguns mais, dentro da própria casa), até prédios públicos, como a Estação Policial e o Conselho Municipal. Nestes locais, seus anfitriões servem comidas, bebidas e lanches aos promesseiros.

15 No momento, não temos o número de altares em que se realizou a dança no ano de 2015. Em 2016, quando também acompanhamos a festa, se dançou perante 41 altares na quarta-feira, véspera de Corpus Christi, e 43 altares na quintafeira, com poucas repetições de lugares nos dois dias. Convém citar que, além dos altares, também se realiza a dança em outros espaços, como o átrio da igreja local, a sede da confraria, o cemitério, dentre outros. Isto dá uma ideia da intensidade da festa, e nos demonstra a necessidade de georreferenciar informações obtidas, localizando e descrevendo esses espaços de performances identificados de forma geral neste artigo, e apresentando a própria forma de experimentar e representar o espaço que seja intrínseca a tais agentes.
} 
presente, para que outra legião de diabos ocupe seu lugar e repita o mesmo processo.

Enquanto estão dançando ou ajoelhados, alguns promesseiros emitem alguns gritos contínuos, numa representação teatral de exorcismo e que, ademais, afirmam ser também uma forma maliciosa de chamarem o Diabo para burlarem-se dele, afinal, o poder do Santíssimo e dos amuletos e penduricalhos que carregam os protege de suas influências. Além disso, é importante frisar que o gesto de dançar "máscara abajo" é uma forma de respeito perante a divindade para a qual dançam, e também simboliza uma atitude de penitência e um reconhecimento, tanto por parte dos promesseiros quanto dos diabos que representam, do poder divino ali presente.

Os diablos, com exceção daqueles descritos no Quadro 1 que vestem indumentárias rituais sem máscara, não se apresentam diante dos altares, do corpo eclesiástico e do próprio Santíssimo Sacramento com o rosto descoberto. Nos outros momentos da festa, podem colocar a máscara diretamente no rosto (“máscara arriba”), quando a dança é predominantemente uma amostra de picardia e exibição pessoal, mas que também serve para repassar suas técnicas corporais aos mais novos, em especial às crianças.

Para iniciarem suas danças, os Diablos de Yare têm que se dirigir, ao meiodia da véspera de Corpus Christi, à frente da igreja paroquial, no centro do povoado, para pedir permissão e receber a benção do pároco local, Francisco "Pancho" Mijares. Em 2015, o pedido de permissão para dançar o Corpo de Deus foi realizado pelo Primero Capataz Pablo Azuaje, que, após uma cerimônia cívica de entrega de condecorações realizada na Plaza Bolívar de Yare, solicitou que "[...] el sacerdote nos llene de agua bendita y no se nos meta el maligno" (AZUAJE, apud MIP-TUY AGENCIA, 2015, p. 5), ao qual o Padre Pancho aquiesceu, jogou água benta nos diablos presentes, celebrou uma breve homília e juramentou os novos Promeseros16.

Após esse primeiro rito, os diablos realizaram suas danças neste dia, na quinta-feira de Corpus Christi e no domingo subsequente (oitava de Corpus), e em diversos locais: na frente da igreja, antes e depois da realização de missas; nas ruas, durante as procissões em que o corpo eclesiástico avançava levando a Custódia17 sob um pálio e, simultaneamente, os diablos, posicionados de frente para o Santíssimo Sacramento, recuavam dançando, repelidos pela santidade ali presente; na frente dos altares instalados em diversos pontos do povoado por promesseiros; na sede da confraria, antes do início e ao final das atividades de

\footnotetext{
${ }^{16}$ Foram juramentados cerca de 20 novos Promeseros, todos bem jovens, a maioria ainda crianças. Antes de serem juramentados, estes Promeseros tiveram que passar por uma preparação realizada pela Igreja, que consiste no catecismo.

17 Custódia ou Ostensório é uma peça de ourivesaria na qual se expõe a hóstia consagrada para a adoração dos fieis durante o culto católico. Em Yare, o ano de 2015 marcou a retomada da procissão com o próprio Santíssimo Sacramento pelas ruas do povoado, acontecimento que não ocorria há cerca de cem anos, pois em seu lugar eram levadas medalhas que o representavam. O Padre Pancho enfatizou esse acontecimento, dizendo que representava que "o Corpo de Deus estará presente em vida” entre seus fieis, e, ademais, ressaltou que as medalhas são relíquias, objetos que, segundo ele afirmou, estão associados aos santos católicos e não ao Santíssimo Sacramento.
} 
cada dia; durante o Velório da Cruz do Calvário18; e no cemitério, em honra e respeito aos seus antepassados.

\section{SENTIDOS SIMBÓLICOS E SIGNIFICADOS POLÍTICOS E SOCIAIS DOS DIABLOS DE YARE}

De acordo com Geertz (2008, p. 66), as religiões também são sistemas de concepções herdadas que se expressam "[...] em formas simbólicas por meio das quais os homens comunicam, perpetuam e desenvolvem seu conhecimento e suas atividades em relação à vida”. No caso dos Diablos de Yare, é possível agregar esse ponto à base sobre a qual se refletirá acerca das trocas simbólicas que atores sociais leigos e eclesiásticos realizam entre si, ora de formas complementares, de modo que uma reforce a outra, ora com certo grau de conflito - nesse ponto, considerando seus aspectos rituais (TURNER, 2008) -, em que, de um lado, há tentativas de enquadramento e, no outro, contestações por vezes simbólicas e não sistematicamente deliberadas -, refratações, ressignificações e retraduções de sentidos.

Embora tais trocas simbólicas possam ser analisadas em diversos aspectos das religiões, o que reserva ao campo religioso força e riqueza em significados e aspectos socioculturais que contribuem para que possamos compreender dadas sociedades, enfatizamos de forma especial a questão da mística, aspecto presente em várias ou quase todas as formas de religião.

Sendo um dos tipos ideais formulados por Max Weber (1864-1920), a mística ou misticismo irá se distinguir daquele tipo ideal que pode ser considerado como o seu oposto, a ascese. Assim, enquanto esta se refere ao comportamento disciplinado, em que o fiel controla seus impulsos naturais e anseia controlar o mundo, aquela envolve uma relação de proximidade ou até mesmo intimidade com as entidades sobrenaturais, das quais o fiel pode se considerar e se ver como um receptáculo (MAUÉS, 2014; MARIZ, 2003).

Logo, se a dicotomia mística-ascese empreende distintas racionalidades religiosas, como destaca Mariz (2003), as formas, regras e disciplinas para o exercício da religião que cada lado desse par ideal engendra podem, em determinadas situações, não ter contradições tão acentuadas, conforme Maués (2014) enfatizou, afinal, os tipos ideais frequentemente apresentam-se combinados ou em estado de transição.

Apesar de a mística ser um aspecto muito evidente, há diversos tempos e espaços nos Diablos de Yare para que movimentos de racionalidade ascética se realizem, representando, desse modo, o resultado de um processo históricosocial que deslocou o outrora periférico na festa de Corpus Christi na Venezuela

18 Os chamados Velórios de Cruz são festividades em que se constroem um altar em um espaço público, adornado com velas e círios, cintas de diversas cores e lençóis brancos, com uma cruz no meio, vestida de flores e acompanhada de frutas oferecidas aos fieis. Durante sua realização, os presentes entoam fulías em honra da cruz bendita, e se servem de comidas e aguardente. Há alguns anos os Diablos de Yare adaptaram essa expressão cultural-religiosa, integrando-a ao ritual de sua festa, como forma dos promesseiros das comunidades distantes do centro de Yare terem um lugar onde passar as noites durante a realização da festa. 
para o centro da festividade, permitindo a promesseiros oriundos de classes sociais subalternizadas tornarem-se ícones ao dançar vestindo indumentárias rituais e luzindo máscaras de diabos perante o próprio Corpo de Cristo.

Marcado por complexas relações que a dicotomia mística-ascese provoca, evidencia-se o caráter eminentemente dramático e conflituoso desse ritual, com a festa ali celebrada assumindo a característica de uma série de mediações que se realizam em diversificadas performances que se distribuem temporal e espacialmente por Yare.

Festa que pode ser pensada também a partir de perspectivas teóricointerpretativas da antropologia do conflito, uma vez que as disputas assumem distintas feições, o que torna importantes as formas de relação que ocorrem de diversas maneiras possíveis entre os corpos sociais que dela tomam parte (corpo eclesiástico, membros da confraria, agentes públicos, espectadores, comerciantes), resultando diversos tipos de agenciamentos e enquadramentos, com suas exortações, observações e mecanismos explícitos ou implícitos acionados para regular o comportamento dos participantes da festa e/ou se apropriarem de seus sentidos e significados.

A maior parte desses agenciamentos e enquadramentos são a priori mais visíveis nos discursos públicos. Exemplificando esta questão, citamos as reiteradas vezes em que o padre e outros membros do corpo eclesiástico enfatizavam que aquela festa tinha um caráter distinto e estritamente religioso, e exortava os fieis e demais acompanhantes para que tivessem compostura, que observassem o jejum, que evitassem o concubinato e que se abstivessem do consumo de bebidas alcoólicas19.

Apesar dessa demarcação da Igreja Católica do caráter distinto e estritamente religioso da festa, também houve a entrega de medalhas de ordem e de distinções civis a 26 pessoas20, além da presença de autoridades públicas, como deputados, prefeito municipal e a visita do atual governador do estado Miranda, Henrique Capriles Radonski21, demonstrando que esta ocasião social também é composta de significados políticos e cívicos, com seus respectivos discursos de agenciamento e enquadramento.

Integrados a um complexo processo no qual os rituais22 que desenvolvem são elementos propulsores que ligam e religam suas diferentes fases e os interesses multifacetados (CAVALCANTI, 2013) que nele se encontram, e que possui pelo menos um momento no qual seus participantes libertam-se de

\footnotetext{
${ }^{19}$ Num acordo entre a Igreja e o Governo local, foi anunciado que a comercialização de bebidas alcoólicas estava proibida durante os dias de realização da festa. No entanto, a comercialização ocorreu como se não houvessem restrições, inclusive em estabelecimentos próximos à igreja e sob a vista de agentes de segurança do Estado, estendendose até a madrugada, num volume que, de acordo com alguns comentários coletados, era muito maior do que o comercializado no povoado em qualquer outra época do ano, e com a presença de pessoas contratadas pelas cervejarias nacionais para a realização de ações localizadas de marketing.

20 Medalhas da Ordem "Generalísimo Francisco de Miranda", "Manuel Salvador Sanoja" e "Buen Ciudadano", outorgadas pelo Conselho Legislativo do Estado Miranda, e distinção Corpus Christi, pela Prefeitura Municipal de' Simón Bolívar.

21 A presença de Capriles, em especial, trouxe um pouco de tensão para o lugar, pois o atual governador de Miranda é um dos principais membros da oposição ao governo federal, tendo sido candidato a presidente por duas ocasiões (em 2012, na qual perdeu para o então presidente Hugo Chávez, e em 2013, em eleição disputada contra o atual presidente Nicolás Maduro Moros, após o falecimento de Chávez), enquanto as demais autoridades políticas presentes na festa eram todas partidárias do governo federal e havia a presença de muitos militantes do Partido Socialista Unido da Venezuela (PSUV), o principal e maior partido da base governista.

22 Para uma revisão de teorias que tratam sobre rituais, confira Neves (2005).
} 
exigências normativas e ficam "[...] betwixt and between sucessivas posições em sistemas jurídico-políticos” (TURNER, 2008, p. 11-12), os Diablos de Yare empreendem ações simbólicas nesta ocasião eminentemente dramática em que participam tanto ao negociarem resultados, quanto ao se posicionarem estrategicamente, com disputa e consolidação de poder (NEVES, 2005).

As diversas posições que os Diablos de Yare ocupam no decorrer de seu processo ritual colocam-nos entre contraposições de figuras antitéticas do imaginário cristão. Não obstante, retiram dessas (contra)posições sensos de determinação moral que canalizam suas energias e esforços - um promesseiro nos resumiu o sentido que atribui à festa, explicando-nos que, enquanto "uno está pagando su promesa como humano, el diablo está pedindo perdón a Dios".

Durante o ritual, realizam inversões e subversões de interesses e exigências normativas seculares e religiosas. Nelas, utilizam as potencialidades metafóricas que a festa lhes proporciona para marcar, mediante a realização da communitas, seus processos de vida enquanto sujeitos concretos, históricos e idiossincráticos (TURNER, 2013), uns em relação aos outros. Dinamizam, em um ritual de rebelião, estruturas e antiestruturas sociais, ao se movimentarem no ínterim das fases em que a dança se liga à celebração litúrgica e em que se torna mais ou menos independente dela.

Porém, enquanto ritual de rebelião, os Diablos de Yare questionam somente distribuições particulares de poder, não a própria estrutura do sistema, apresentando-se contra a ordem estabelecida, mas objetivando conseguir prosperidade por meio dessa mesma ordem (GLUCKMAN, 2011). E o fazem ao se liberarem de controles estruturais e constituírem relacionamentos não estruturados no decorrer das fases liminares do ritual, isto, pela dramatização da estrutura e da antiestrutura nos diversos espaços da festa (TURNER, 2013).

A narrativa que apresentamos anteriormente nos ilustra esse caráter de ritual de rebelião que o contexto possui. Vejam como ali se coloca o drama social nos elementos que revelam algumas das tensões que marcaram aquele tempo de que trata a narrativa, e que se espraiam para os dias atuais, mesmo se apresentadas por meio de elementos alegóricos que as vincula com o natural e o sobrenatural (Quadro 2).

Quadro 2 Fases do drama social na narrativa do senhor Ponte Bello

\begin{tabular}{|c|l|}
\hline Fases do drama social & \multicolumn{1}{c|}{ Evento } \\
\hline Ruptura ou separação & a estiagem. \\
\hline $\begin{array}{c}\text { Crise e intensificação da } \\
\text { crise }\end{array}$ & a estiagem vista como força demoníaca. \\
\hline Ações remediadoras & $\begin{array}{l}\text { (1) a convocatória do padre. } \\
\text { (2) a decisão dos escravizados em atender ao chamado para a } \\
\text { missa mesmo sendo-lhes proibido entrar na igreja e levando seus } \\
\text { instrumentos de resistência (máscaras e tambores). } \\
\text { (3) os diabos chegam à porta da igreja e o padre os repele com } \\
\text { água benta. }\end{array}$ \\
\hline Reintegração & $\begin{array}{l}\text { a chuva que cai sem nenhuma explicação aparente, mas marca o } \\
\text { alcance de uma situação de equilíbrio, em que todos dançam, os } \\
\text { negros de um lado e os brancos de outro. }\end{array}$ \\
\hline
\end{tabular}

Fonte: Turner (2008) e Trabalho de campo (2015). 
Embora tenham confrontado a ordem social vigente à época colonial, que não permitia aos escravizados o acesso à igreja, o questionamento que realizam, apesar da contundência de portarem seus artefatos de resistência (máscaras, tambores, maracas), cessa quando chegam à situação de equilíbrio em relação aos efeitos da estiagem, reintegrando-se à estrutura do sistema - a dança apartada dos grupos sociais é elemento de destaque nessa reintegração -, mas dando origem a uma festa que, se manterá os vínculos com a Igreja Católica, gigantesca instituição de poder cuja marca foi, durante o período colonial venezuelano, o duplo discurso face à instituição da escravidão, o fará mediante contestações, refratações e negociações de projetos de ação com esta instituição e com o Estado, sobretudo após a patrimonialização da festa.

Empreendendo suas ações rituais a partir dessa forma de relacionamento humano que se contrapõe à forma estruturada e hierarquizada da interação social, que Turner (2013) denominou de comunnitas, na festa dos Diablos de Yare há embate entre os corpos sociais e os agenciamentos e enquadramentos que cada um deles quer impor à festa, que, mesmo se aceitos publicamente, também são passíveis de formulações e reformulações de contestações, que, mediante o que Scott (2000) denomina de infrapolítica, podem ser levadas de forma disfarçada ao espaço público.

Partindo disto, é possível de se pensar que o entrelaçamento e as mediações das hierarquias formal e ritual da confraria se deem de forma que a primeira permita aos Diablos de Yare adequarem-se a determinados padrões de organização que lhes são solicitados para acessarem meios específicos de apoio a suas atividades (o reconhecimento como Patrimônio Cultural da Humanidade, por exemplo) - embora nesse movimento recebam determinadas imposições -, e que a segunda represente, dentre outros pontos, a ressignificação, a retradução ou até mesmo a refratação de algumas dessas imposições no momento de realização da festa23.

Desses movimentos, surge o que enxergamos como mediações verticais, horizontais e oblíquas que (con)formam e (re)elaboram uma etnopolítica dos Diablos de Yare, e que se dão de acordo com a forma que decidem adotar para se colocar em cena - performar, portanto - face às posições e situações em que se encontram e que experimentam no que podemos definir como um Campo de Relações dos Diablos de Yare, que se intersecciona com campos políticos (não podemos perder de vista o contexto, importante para estudos de festas e rituais, de crise que tem demarcado a Venezuela desde pelo menos a chegada a Chávez à presidência, e que só tem aumentado desde então), religiosos e, a partir do processo de sua patrimonialização em nível nacional e internacional, patrimoniais. Todos carregados de tensão, disputas e enquadramentos.

23 Tal hipótese levantada reforça a perspectiva dos Diablos de Yare como um ritual de rebelião, que chega a contestar alguns aspectos estruturais mesmo utilizando-se do sistema contestado ritualmente para obter algum tipo de ganho. Desse modo, não se pode colocar as hierarquias formal e ritual como se uma estivesse situada nos antípodas da outra. Nesse caso, a realidade é mais complexa do que o pensamento pode abarcar, e por isso utilizamos os termos entrelaçamento e mediações, pois uma e outra estabelecem relações de trocas e influências mútuas, o que resultaria em uma organização dos Diablos de Yare mais complexa e inclusive mais avançada do que a forma de organização prescrita pelos enquadramentos técnico-racionais que venham a sofrer. 


\section{CONSIDERAÇÕES FINAIS}

Durante a realização da festa dos Diablos de Yare há uma série de usos do espaço que são próprios à festividade e que por isso se distinguem daqueles que se desenvolvem de forma mais ordinária neste povoado. Considerando-se que nos espaços existentes em Yare coexistem múltiplas sociabilidades contrastantes, em que cada grupo ou coletivo de indivíduos propõe usos específicos em função da posição que ocupa em um campo de relações sociais e da situação que experimentam no interior desse campo, deve-se também salientar que durante a realização da festa, a ordem pública que caracteriza os usos cotidianos do espaço é confrontada e substituída por uma ordem distinta, própria dos fluxos de sentidos e significados desse ritual de danças.

Assim, as festas, principalmente as que se dão em espaços públicos, seriam não somente situações harmônicas de culto às tradições e costumes, mas também situações prenhes de conflitos, de virtualidades, de energias e de potencialidades que nem sempre possuem uma finalidade definida e que, enquanto buscam equilibrar e mesmo "anular" alguns tipos de interações afetivas, religiosas, culturais, econômicas, financeiras e administrativas (ampliando-se a abrangência desse termo ao retirar-lhe a denotação que o vincula exclusivamente à noção de management), manifestam nessas mesmas dimensões outros tipos de interações que se distinguem quantitativa e qualitativamente.

Portanto, além de sua característica cultural e religiosa, os Diablos de Yare movimentam aspectos sociais, étnicos, políticos e econômicos, o que os define como um tipo de manifestação cultural popular compósita. Situações que se desenvolvem em ocasiões sociais desse tipo, que, além do mais, possuem um caráter religioso que as carrega de significações que remetem a elementos legíveis do real e do imaginário dos grupos sociais que as vivenciam, são dotadas de um forte valor sociocultural e ricas de significados e sentidos que se trocam e que se entrelaçam, permitindo-nos entender o caráter dinâmico de suas relações sociais, nas quais o movimento pode ser visto como estrutura, assim como a "[...] persistência enquanto um notável aspecto da mudança" (TURNER, 2008, p. 27).

Ter observado que o ritual da dança pulsa em ligações e desligamentos com a liturgia católica nos diferentes espaços de realização da festa, nos permitiu entender a dinâmica do binômio mística-ascese que nela atua. Quando ligados diretamente à liturgia, os dançantes demonstram uma preocupação com o controle de alguns de seus impulsos, reforçada nas reiteradas vezes em que o padre e outros membros do corpo eclesiástico enfatizavam e exortavam os promesseiros para que "recuperassem a honra e a ternura", de forma que fossem "diablos buenos", numa síntese de elementos tão antitéticos.

Após os atos litúrgicos, a Igreja fechava suas portas, e, embora seu discurso ainda ecoasse nos corpos de quem os escutara, tais ecos ficavam cada 
vez mais longe e encobertos pelo batuque da caja e o chacoalhar das maracas. Neste momento, as danças se tornam mais intensas e o caráter estruturante que possuem nessa experiência religiosa aumenta a relação de proximidade com o Santíssimo24.

Ademais, a aproximação dos fieis tanto com o divino quanto com o maligno, embora de formas diferentes, apesar de unidas, se destaca como um aspecto interessante na mística dos Diablos de Yare. No relacionamento com o divino, cuja presença no ritual é real, dada a "produção de presença" do corpo de Cristo, que se forma pelos diversos corpos sociais em procissão, tem-se a reverência, a exaltação do seu poder sobre o Mal e a amplificação de sua presença pelo toque da caja - que funciona como música de chamamento.

Por outro lado, o relacionamento com o maligno, cuja presença é representada para que o próprio Mal seja conjurado e esconjurado simultaneamente, com o toque da caja servindo neste momento como música de esconjuração, torna-o alvo de escárnio e de uma série de atos para proteger os dançantes de uma indesejável possessão, o que, se não torna real a presença dessa figura que condensa uma série de significados, deixa-a sempre iminente. Portanto, o ser humano, o diabo e Deus se encontram e realizam trocas entre si neste momento, como expressa a frase que destacamos alguns parágrafos acima: "uno está pagando su promesa como humano, el diablo está pedindo perdón a Dios".

O complexo processo do ritual de rebelião constituído pela festa dos Diablos de Yare é uma ocasião dramática, que assim se caracteriza pela latência de conflitos, com suas dimensões por vezes inconscientes, produzida na vida social pela atuação constante dos princípios estruturais contraditórios que nela se encontram. É um processo que se constitui por símbolos em movimento e por sistemas em ação, que conformam o sentido vivido (sense of ritual) nessa experiência social (CAVALCANTI, 2013).

Tratamos, portanto, de uma festa que se constitui em um campo de relações no qual emergem cenas de performances (scènes de performances), nas quais os sujeitos rituais movimentam discursos e distinções cívicas, operacionalizam categorias como patrimônio e tradição, e apresentam ou suscitam narrativas que, assim como aquelas que ouvimos do senhor Ponte Bello, desmantelam os pressupostos da verdade histórica oficial, gerando visões alternativas a questões-chave da (con)formação da nação venezuelana e dos elementos de sua identidade nacional, antecipando problemáticas que só atualmente têm sido reconhecidas pelos meios acadêmicos e pelos aparelhos de Estado.

Com relação às narrativas, embora tenhamos apontado anteriormente seu caráter de interpretação a posteriori, não significa desqualificar o que ouvimos, mas, pelo contrário, evidencia algo importante: a interpretação ordinária de fatos que marcam o imaginário social de grande parte dos cidadãos

24 No entanto, em alguns momentos, em especial nas danças que eram realizadas na Casa de los Diablos, sede da confraria, parecia que alguns dos promeseros realizavam aquela dança ritual para a caja, tal qual ocorre no candomblé, onde os tambores são eles próprios entidades por meio das quais se invocam outras entidades. 
venezuelanos, emprestando-lhes sentidos políticos que reorganizam a ordem de importância tanto dos espaços e localidades em que se sucederam significativos acontecimentos para a história nacional - o local de nascimento de Simón Bolívar, por exemplo -, quanto do tempo em que tais eventos se sucederam - o início das revoluções que mais impactaram na constituição do que é a nação venezuelana atualmente e, no nosso caso, a origem dos Diablos de Yare.

Não nos cabe fazer um exercício de historicismo para reconstituir o fato tal como ele teria ocorrido, no qual a reconstrução de processos sociais, em que se corre o risco de se perder ou ocultar e invisibilizar expressões, detalhes e destaques na formalidade do discurso dos pesquisadores. Incorrer na busca de tal restauração ser-nos-ia politicamente ineficaz e perigoso, e eticamente problemático.

Em sua narrativa, que sistematizamos no Quadro 2 anteriormente apresentado, Ponte Bello expressa tensões e dramatizações que nos parecem mais significativas para o entendimento dos aspectos simbólicos da festa que vimos estudando do que nos oferece a historiografia sobre ela. Esse relato, enquanto memória e tradição oral, nos introduz algo mais interessante, sujeito ao tempo e suas intermitências, mas que abre um infinito de possibilidades de exploração dessa tensão dialética entre lembrar e esquecer, na qual não se eliminam as experiências, mesmo se traumáticas, como foi o monumento da escravidão, pois as ressignifica pela construção de relações entre o próximo e o longínquo.

Qualquer que seja seu objetivo ostensivo, apresentado sempre como a luta do Bem contra o Mal (no sentido cristão, é importante destacar), uma característica marcante dos Diablos de Yare é a maneira como revela, enquanto ritual de rebelião, tensões sociais, às quais se somam àquelas inerentes à sua patrimonialização, que os deixará em maior contato com o discurso, as performances, os enquadramentos e as mediações estatais, as não se sujeitam apenas de forma passiva.

É possível que as representações simbólicas e dramáticas dessas relações sociais, com todas suas ambivalências, propiciem a emergência de espaços de contestação mais amplos, em que também ponteiem sua condição patrimonial na constituição de uma etnopolítica dos Diablos de Yare. Afinal, suas atitudes rituais são $\mathrm{f}(\mathrm{r})$ estas utilizadas de distintas formas para que se coloquem no mundo, via gestos, toques, danças, enfim, corporeidades específicas às culturas de resistência.

\section{BIBLIOGRAFIA}

BERMÚDEZ, E.; MARTÍNEZ, G. Hugo Chávez: la articulación de un sentido para la acción colectiva. Espacio Abierto, Maracaibo, v. 9, n. 1, p. 53-77, jan.mar. 2000. Disponível em: <http://www.redalyc.org/pdf/122/12290104.pdf>. Acesso em: 19 mai. 2017. 
BRUCE, M. Estado e democracia nos tempos de Hugo Chávez (1998-2013). São Paulo: Editora FGV, 2016.

CADENAS UZCÁTEGUI, S. Sincretismo cultural en dos tradiciones venezolanas. Revista de Artes y Humanidades ÚNICA, Maracaibo, v. 11, n. 1, p. 107-130, jan.-abr. 2010. Disponível em: <http://www.redalyc.org/articulo.oa?id=170121894005>. Acesso em: 27 set. 2014 .

CAVALCANTI, M. L. V. C. Drama, ritual e performance em Victor Turner. Sociologia \& Antropologia, Rio de Janeiro, v. 3, n. 6, p. 411-440, jul.-dez. 2013. Disponível em: <http://revistappgsa.ifcs.ufrj.br/wpcontent/uploads/2015/o5/4-anoo3no6_maria-laura-viveiros-de-castrocavalcantii.pdf>. Acesso em: 01 jul. 2015.

GALLEGOS, R. Pobre Negro. Caracas: Editorial Panapo, 1985.

GARCÍA GAVÍDIA, N. Máscaras y representaciones del diablo en las fiestas del Corpus Christi. Un estudio de Antropología comparada entre España y Venezuela. In: DEL PINO, F (Coord.). Demonio, religión y sociedad entre España y América. Madrid: CSIC, 2002. p. 323-368.

GEERTZ, C. A religião como sistema cultural. In: das culturas. 1 ed. 13 reimp. Rio de Janeiro: LTC, 2008. p. 65-91. A interpretação

GLUCKMAN, M. Rituais de rebelião no sudeste da África. Série Tradução, Brasília, v. 1, n. 3, s.p., 2011. Disponível em: <http://www.dan.unb.br/images/pdf/serie-traducao/st\%2003.pdf>. Acesso em: 25 mar. 2015 .

INSTITUTO NACIONAL DE ESTADÍSTICA - INE. XIV Censo Nacional de Población y Vivienda. Resultados por Entidad Federal y Municipio del Estado Miranda. Caracas: INE, 2013. Disponível em: <http://www.ine.gov.ve/documentos/Demografia/CensodePoblacionyVivienda /pdf/miranda.pdf $>$. Acesso em: 28 set. 2014.

MARIZ, C. L. A sociologia da religião de Max Weber. In: TEIXEIRA, F. (Org.). Sociologia da religião: enfoques teóricos. Petrópolis, RJ: Vozes, 2003 p. 67-93.

MARTÍN, R. ¿Triunfa el bien sobre el mal? Caracas: Fundación Editorial El perro y la rana, 2015 .

MAUÉS, R. H. A mística em algumas formas de manifestações religiosas. Debates do NER, Porto Alegre, v. 2, n. 26, 193-227, jul./dez. 2014. Disponível em: <http://seer.ufrgs.br/index.php/debatesdoner/article/view/52049/32072>. Acesso em: 24 mar. 2015.

MAUSS, M. El concepto de la técnica corporal. In: Sociologia $y$ Antropologia. 1. ed. 1 reimp. Traducción Teresa Rubio de Martin-Retortillo. Madrid: Editorial Tecnos, 1979. p. 337-343. 
MIP-TUY AGENCIA. Diablos de Yare con permiso para danzar este jueves de Corpus Christi. Diario La Voz, Caderno Valles del Tuy, p. 5, Guarenas, o4 jun. 2015 .

NEVES, R. C. M. Dramas e performances: o processo de reelaboração étnica Xukuru nos rituais, festas e conflitos. 2005. 239 f. Tese (Doutorado em Antropologia Social) - Centro de Filosofia e Ciências Humanas, Universidade Federal de Santa Catarina, Florianópolis, 2005.

RAMOS GUÉDEZ, J. M. Orígenes de la festividad de los Diablos Danzantes en Venezuela. Boletín de la Academia Nacional de la Historia, Caracas, tomo XCII, n. 366, p. 165-173, abr.-jun. 2009. Disponível em: <http://tuymiciudadcom.webs.com/documents/Jose-20Marcial-20Ramos-20Guedez.pdf $>$. Acesso em: 25 jul. 2014.

SANTOS, B. C. C. O Corpo de Deus na América: a festa de Corpus Christi nas cidades da América Portuguesa - Século XVIII. São Paulo: Annablume, 2005.

SCOTT, J. C. Los dominados y el arte de la resistencia. Discursos ocultos. Traducción Jorge Aguilar Mora. México, DF: Ediciones Era, 2000.

TURNER, V. O processo ritual: estrutura e antiestrutura. Tradução de Nancy Campi de Castro e Ricardo A. Rosenbusch. 2. ed. Petrópolis, RJ: Vozes, 2013.

Dramas, Campos e Metáforas: ação simbólica na sociedade humana. Tradução Fabiano de Morais; revisão técnica Arno Vogel. Niterói: Editora da Universidade Federal Fluminense, 2008.

\section{Recebido em 10/06/2017.} Aprovado em 24/07/2017. 